\title{
Determination of antiradical activity and phenolic and flavonoid contents of extracts and fractions of jackfruit (Artocarpus heterophyllus Lamk) seeds
}

\author{
Zubaydah, W.O.S., Sahumena, M.H., Fatimah, W.O.N., Sabarudin, Arba, M. and *Yamin
}

Pharmacy of Departement of Halu Oleo University, Kendari City, Indonesia

\begin{abstract}
Article history:
Received: 6 October 2020

Received in revised form: 11

November 2020

Accepted: 1 Jnauary 2021

Available Online: 18 April 2021
\end{abstract}

Keywords:

2,2-diphenyl-1-

picrylhydrazyl,

Antiradical activity,

Jackfruit seeds,

Total phenolic content,

Total flavonoid content

DOI:

https://doi.org/10.26656/fr.2017.5(3).563

\begin{abstract}
Jackfruit (Artocarpus heterophyllus Lamk) is a plant from the Moraceae family that is widespread in Indonesia. Empirically, jackfruit can be used to cure hypertension, diabetes, cancer, asthma, dermatosis, coughs, wounds, acne, and diarrhea. The bioactive compounds in jackfruit include phenolics and flavonoids, which function as natural antioxidants. This research investigated the antiradical activity of jackfruit seed extracts and fractions using DPPH (2-2-diphenyl-1-picrylhydrazyl) and examined the total phenolic and flavonoid contents which may be developed as functional medicines and foods. The jackfruit seed powder was extracted using the maceration method. Radical scavenging activities were measured using the 2,2-diphenyl-1-picrylhydrazyl (DPPH) method. Total phenolic contents were determined using the Folin-Ciocalteu method. Meanwhile, the contents of flavonoids were determined using the aluminum chloride complex colorimetric method. The $\mathrm{IC}_{50}$ value of ethyl acetate fraction, methanol extract, $n$ -hexane fraction, and water fraction was $5.435 \pm 0.064 \mu \mathrm{g} / \mathrm{mL}, 5.639 \pm 0.302 \mu \mathrm{g} / \mathrm{mL}$, $7.201 \pm 0.475 \mu \mathrm{g} / \mathrm{mL}$, and $9.134 \pm 0.2911 \mu \mathrm{g} / \mathrm{mL}$, respectively. The phenolic and flavonoid contents of ethyl acetate fraction, methanol extract, $n$-hexane fraction, and water fraction were $49.597 \pm 1.589,47.949 \pm 1.966,41.214 \pm 4.354$ and $35.504 \pm 0.913 \mathrm{~g}$ GAE $/ 100 \mathrm{~g}$ of sample, respectively for phenolic, and $70.199 \pm 0.458,65.228 \pm 0.615,59.907 \pm 0.719$, and $54.234 \pm 0.351 \mathrm{~g}$ of quercetin equivalent $/ 100 \mathrm{~g}$ of sample, respectively of flavonoids, with a correlation value $\left(\mathrm{R}^{2}\right)$ to antiradical power of 0.4582 for phenolic and 0.5281 for flavonoids. The ethyl acetate fraction of jackfruit seeds can be further developed as an anti -radicals and functional food.
\end{abstract}

\section{Introduction}

Jackfruit (Artocarpus heterophyllus L) is a plant of the Moraceae family, which is widely grown in Indonesia and other tropical countries such as Brazil, Thailand, the Philippines, and Malaysia. The seeds can usually be consumed as snacks by roasting, boiling, or steaming them (Burci et al., 2015). Jackfruit can be consumed directly and also in the form of a jackfruit salad, which has high nutrition. In addition, jackfruit is also reported to have the antioxidant compound of prenylflavonoids (Gupta et al., 2011). Empirically, jackfruit can help to cure hypertension, diabetes, cancer, asthma, dermatosis, coughs, wounds, acne, and diarrhea (Moke et al., 2017; Ilmi et al., 2020).

In order to explore local food sources that have been used from generation to generation as medicine and have economic value, it is necessary to investigate the bioactive compounds in these foods. Among the bioactive compounds that are abundant in plant foods and have antioxidant functions are phenolic compounds. Oxidants are reactive oxygen species (ROS), which are species that are produced continuously by animals and humans that have the dual function of damaging and repairing the body's biological systems (Burci et al., 2015). Antioxidants are needed by the body because they have the ability to delay substrate oxidation by inhibiting initiation and propagation caused by oxidation reactions from free radicals (Azlim Almey et al., 2010; Widodo et al., 2020). In addition, ROS also has a role in the process of food spoilage through lipid autoxidation and enzymatic oxidation that occurs during the storage process of fats, oils and foods containing fat (Matthaus, 2002).

Synthetic antioxidants, such as butyl hydroxyanisole (BHA), tert-butylhydroquinone (TBHQ), propyl gallate (PG), and butylated hydroxytoluene (BHT) have been 
widely used in the world, but synthetic antioxidants have side effects, such as cytotoxicity to the heart and lungs, and are carcinogens (Azlim et al., 2010; Sulastri et al., 2018). In addition, butyl hydroxyanisole (BHA) and butylated hydroxytoluene (BHT) also have low solubility and have moderate antioxidant power (Sannigrahi et al., 2010). Therefore, a lot of recent research has been attempting to discover antioxidant compounds from natural ingredients, which are believed to have a high activity level and lower toxicity than synthetic compounds (Rohman et al., 2010), for example, rambutan peel (Mistriyani et al., 2018), Moringa oleifera leaves (Fitriana et al., 2016), and extracts and fractions from the peel of avocado (Persea Americana Mill), which were observed in vitro (Antasionasti et al., 2017). Therefore, the objectives of the research were to investigate the potential of jackfruit seed extract and fraction as antiradical and examine its total phenolic and flavonoid content.

\section{Materials and methods}

\subsection{Materials}

The materials used in this research were ripe jackfruit that was obtained from Pebaoa Village, North Buton Regency, Southeast of Sulawesi Province, methanol, ethyl acetate, $n$-hexane, DPPH radicals (Sigma -Aldrich $\AA$ ), Folin-Ciocalteu reagent (Sigma-Aldrich ${ }^{\circledR}$ ), aluminium chloride, gallic acid, and quercetin.

\subsection{Extraction}

Jackfruit seeds were covered with a black cloth and dried in the sun. The dried seed of the jackfruit was pulverized into powdered form. After that, jackfruit seed powder (350 g) was macerated using methanol for $3 \times 24$ hours. The solvent was replaced every 24 hours. The extract that was obtained from maceration was concentrated using a rotary evaporator in order to obtain methanol extract.

$$
\text { Extract yield }=\frac{\text { Weight of the extract }}{\text { Weight of the simplicia }} \times 100 \%
$$

\subsection{Fractionation}

A total of $20 \mathrm{~g}$ of methanol extract was dissolved with $200 \mathrm{~mL}$ of warm water and then fractionated using $n$-hexane solvent in order to obtain the $n$-hexane fraction and remaining water. The remaining water was fractionated again using ethyl acetate solvent so that the ethyl acetate fraction was obtained from the remaining water. The $n$-hexane, ethyl acetate, and water fractions were concentrated using a rotary evaporator as shown in Figure 1.

$$
\text { Fraction yield }=\frac{\text { Weight of the fraction }}{\text { Weight of the extract }} \times 100 \%
$$

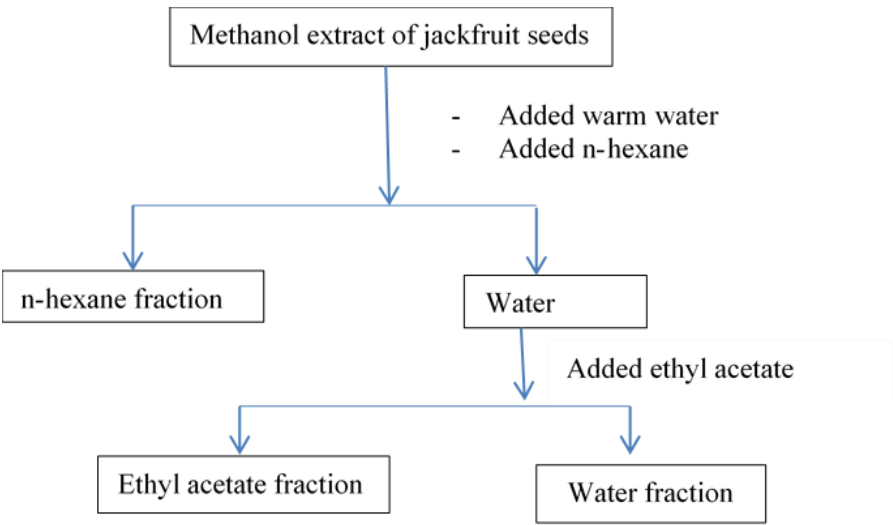

Figure 1. Schematic of fractionation of the methanol extract of jackfruit seeds

\subsection{Phytochemical Screening}

Phytochemical screening was conducted as in the phytochemical screening on Raghu bark (Dracontomelon dao (Blanco) Merr) extracts conducted as follows (Yamin et al., 2020).

\subsubsection{Alkaloids}

A total of $1 \mathrm{~mL}$ of each dissolved extract and fraction was taken and then put into a test tube. Two or three drops of Dragendorff's reagent were added. The formation of a red precipitate indicates the presence of alkaloids.

\subsubsection{Tannins}

The dissolved extracts and fractions were taken as much as $1 \mathrm{ml}$ then put into a test tube and then $1 \mathrm{~mL} \mathrm{Fe}$ (III) chloride $1 \%$ was added. Positive results are indicated by blue-black or green colour.

\subsubsection{Flavonoids}

Jackfruit seed extract and fractions were put into test tubes as much as $1 \mathrm{~mL}$, then heated for 5 mins. Concentrated $\mathrm{HCl}$ was added, then $0.2 \mathrm{~g}$ of magnesium powder was added. Positive results are indicated by the formation of a deep red to magenta colour within 3 mins.

\subsubsection{Saponins}

A total of $1 \mathrm{~mL}$ of each Jackfruit seed extract and fraction was put into a test tube, then $4 \mathrm{~mL}$ of water was added and boiled for 2-3 mins and then cooled and shaken vigorously. The positive result is indicated by white foam that is stable for at least 10 mins.

\subsubsection{Terpenoids}

A total of $1 \mathrm{~mL}$ of each extract and fractions was put into a test tube. Acetic anhydride $(1 \mathrm{~mL})$ was added and then cooled. After it cooled down, concentrated $\mathrm{H}_{2} \mathrm{SO}_{4}$ was added. A reddish-brown colouration indicates positive results for the presence of terpenoids. 
2.5 Measurement of anti-radical activity using the DPPH method

The antiradical activity was determined by following the modified Garcia method (Garcia et al., 2012). Each test sample was taken as much as $1 \mathrm{~mL}$, then $3 \mathrm{~mL}$ absolute methanol and $1 \mathrm{~mL}$ DPPH radical (2,2-diphenyl -1-picrylhydrazyl) were added. The mixture was shaken to homogeneity, then incubated in a dark room for 30 mins. The absorbance was measured using a UV-Vis spectrophotometer at $513 \mathrm{~nm}$. The antioxidant capacity of extract and fraction samples to inhibit DPPH radical can be calculated using the equation below.

$$
\% \text { inhibition }=\frac{A_{c}-A_{s}}{A_{c}} \times 100 \%
$$

Where \% inhibition $=$ DPPH radical inhibition percentage, $A_{c}=$ Absorbance of control and $A_{s}=$ Sample concentration.

Antioxidant activity $\left(\mathrm{IC}_{50}\right)$ was calculated based on the linear regression equation between percent inhibition and the concentration of the sample or fraction, where the $x$-axis was the concentration, while the $y$-axis was the percent inhibition. So, the regression equation $y=b x+a$ was obtained. After that, the $y$ value was replaced by 50 . $\mathrm{IC}_{50}$ is defined as the concentration of the sample that is needed to inhibit $50 \%$ of DPPH radicals (Mistriyani et al., 2018).

\subsection{Determination of total phenolic content}

The total phenolic content of jackfruit seeds and fractions were determined by the Folin-Ciocalteu method according to John et al. (2014). However, in this research, the method was slightly modified. In short, 1 $\mathrm{mL}$ of each concentration series from the sample was taken and then $0.4 \mathrm{~mL}$ of the Folin-Ciocalteu reagent was added. After that, it was shaken, left for 8 mins, and then $4 \mathrm{~mL}$ of $\mathrm{Na}_{2} \mathrm{CO}_{3} 7 \%$ was added. The mixture was shaken to homogeneity, then was added methanol to make $10 \mathrm{~mL}$. The mixture was allowed to stand for 30 mins. After that, absorbance was measured using UVVis spectrophotometer at a wavelength of $647 \mathrm{~nm}$. Measurement of each sample concentration series was conducted three times for replication. Total phenolic content is expressed as grams of Gallic acid equivalent (GAE)/100 g sample.

\subsection{Determination of total flavonoid content}

Total flavonoid content was measured using the colorimetric method (John et al., 2014; Vyas et al., 2015). However, in this research, the method was slightly modified where $10 \mathrm{mg}$ of sample was dissolved with methanol p.a. to $10 \mathrm{~mL}$. Then take $1 \mathrm{~mL}$ and added $3 \mathrm{~mL}$ of methanol p.a., then $0.2 \mathrm{~mL}$ of $10 \%$ aluminium chloride and $0.3 \mathrm{~mL}$ of $1 \mathrm{M}$ potassium acetate were also added. Then, sufficient volume to $10 \mathrm{~mL}$ with aqudest. The mixture was incubated for 30 mins. Then, the absorbance was measured using a UV-Vis spectrophotometer at $439 \mathrm{~nm}$. Measurement was conducted three times. Total flavonoid content is expressed as grams of quercetin equivalent $(\mathrm{QE}) / 100 \mathrm{~g}$ sample.

\subsection{Statistical analysis}

All data in this research were analysed by using the Microsoft Excel program (Microsoft Inc. USA). Data analyses were replicated three times. Values were expressed in average data \pm standard deviation (SD).

\section{Results and discussion}

In this research, the extraction method used was maceration. With maceration, it is expected that metabolite compounds that are not heat-resistant will not be damaged due to high temperatures. Then, the process was continued with fractionation using solvents with different polarity. The purpose of using a solvent with a different polarity is to completely extract constituent compounds-not only non-polar compounds but also semipolar and polar compounds. A compound can be discovered in different solvents, but the level of these compounds in each solvent is different, depending on the distribution coefficient of the compound (Yamin et al., 2010). The results of Jackfruit seeds extraction and fractionation are presented in Table 1. The data showed that the most metabolites in the methanol extract of jackfruit seeds were polar with a yield of $66.15 \%$. This is because a compound will be easily attracted to a suitable solvent, in accordance with the "like dissolves like" principle where the compound will be attracted to a solvent with the same polarity (Amaro et al., 2015).

Table 1. Yield of extract and fraction of jackfruit seeds

\begin{tabular}{|c|c|c|c|}
\hline Sample & $\begin{array}{c}\text { Simplicia/Extract } \\
\text { weight (g) }\end{array}$ & $\begin{array}{l}\text { Extract/Fraction } \\
\text { weight }(\mathrm{g})\end{array}$ & $\begin{array}{c}\text { Yield } \\
(\%)\end{array}$ \\
\hline Methanol extract & 350 & 36.2 & 10.34 \\
\hline n-hexane fraction & & 2.36 & 11.8 \\
\hline Ethyl acetate & 20 & 4.41 & 22.05 \\
\hline Water fraction & & 13.23 & 66.15 \\
\hline
\end{tabular}

\subsection{Phytochemical screening}

The results indicated that the jackfruit seed extract and fractions positively contained alkaloids, flavonoids, terpenoids, tannins, and saponins. However, the water and n-hexane fractions displayed negative results for saponins. These results are shown in Table 2. 
Table 2. Phytochemical screening extract and fraction of jackfruit (A. heterophyllus Lamk.) seeds

\begin{tabular}{|c|c|c|c|c|c|}
\hline \multirow[b]{2}{*}{ Sample } & \multicolumn{5}{|c|}{ Test } \\
\hline & 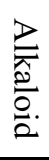 & 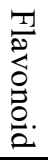 & 节. & $\begin{array}{l}\overrightarrow{0} \\
\stackrel{9}{0} \\
\stackrel{0}{0} \\
\stackrel{0}{2} .\end{array}$ & 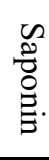 \\
\hline Methanol extract & + & + & + & + & + \\
\hline n-hexane fraction & + & + & + & + & - \\
\hline Ethyl acetate fraction & + & + & + & + & - \\
\hline Water fraction & + & + & + & + & - \\
\hline
\end{tabular}

\subsection{Anti-radical activity test using DPPH (2-2-diphenyl-} 1-picrylhydrazyl)

DPPH radical (2,2-diphenyl-1-picrylhydrazyl) was used in this research because DPPH is one of the radicals that are widely used in a preliminary test to test antioxidants in plants (Jamuna et al., 2012). In addition, DPPH is a stable radical that accepts electron or hydrogen radical to become a stable diamagnetic molecule (Arina and Rohman, 2013) and measurement using DPPH requires a very short time (Sharma and Bhat, 2009; Shekhar and Anju, 2014). In addition, the DPPH assay is also considered as a standard colorimetric technique for measuring the antioxidant activity of plant extracts and pure compounds (Mishra et al., 2012). The antioxidant activity of the jackfruit extract and fractions was measured based on the scavenging activity of the stable 2,2-diphenyl- 1-picrylhydrazyl (DPPH) free radical. In this research, the standard used was vitamin C and methanol was used to dissolve DPPH. Methanol is used as a solvent in the DPPH test because methanol provides a very high sensitivity result compared to other solvents (Rohman et al., 2017)

The reaction between DPPH radicals and antioxidants is marked by a change in colour, from purple to yellow. This colour change is due to the DPPH radicals react with the hydrogen radicals released by compounds that act (Ningsih et al., 2016; Rizkayanti et al., 2017).

Table 3 shows antiradical activity $\left(\mathrm{IC}_{50}\right)$ of jackfruit seed extract and fractions with vitamin $\mathrm{C}$ as a positive control. The $\mathrm{IC}_{50}$ values shown in Table 4 indicated that the ethyl acetate fraction had very strong antiradical activity compared to methanol extract, $n$-hexane fraction, and water fraction. The $\mathrm{IC}_{50}$ value of ethyl acetate fraction, methanol extract, $n$-hexane fraction, and water fraction was $5.435 \pm 0.064 \mu \mathrm{g} / \mathrm{mL}, 5.639 \pm 0.302 \mu \mathrm{g} / \mathrm{mL}$, $7.201 \pm 0.475 \mu \mathrm{g} / \mathrm{mL}$, and $9.134 \pm 0.2911 \mu \mathrm{g} / \mathrm{mL}$, respectively. It indicated that semipolar compounds had very strong antiradical properties. This is in line with the results of previous studies which discovered that the ethyl acetate fraction had stronger antioxidant activity, including ethyl acetate fractions of peels of two rambutan species, namely, rambutan fruits cultivar Binjai and Aceh (Rohman et al., 2017), ethyl acetate fraction of Oroxylum indicum (Linn.) (Trang et al., 2014), ethyl acetate fractions of Polygala sabulosa and Cyathea phalerata (Brighente et al., 2008), ethyl acetate fraction of bark of Pacific walnut (Dracontomelon dao (Blanco) Merr) (Yamin et al., 2020). The antiradical power of a sample, both extract and fraction of a plant, is influenced by the number of hydroxyl groups $(-\mathrm{OH})$ of phenolic and flavonoid compounds in the plant (Brighente et al., 2008)

Table 3. Antiradical activity of jackfruit peel that is described by the $\mathrm{IC}_{50}$ Value $(\mu \mathrm{g} / \mathrm{mL})$

\begin{tabular}{lcccc}
\hline \multirow{2}{*}{ Sample } & \multicolumn{3}{c}{$\mathrm{IC}_{50}(\mu \mathrm{g} / \mathrm{mL})$} & \multirow{2}{*}{\begin{tabular}{c} 
Average \\
\cline { 2 - 4 }
\end{tabular}} \\
\cline { 2 - 4 } $\mathrm{I}$ & $\mathrm{II}$ & $\mathrm{III}$ & $(\mu \mathrm{g} / \mathrm{mL})$ \\
\hline Methanol extract & 5.963 & 5.59 & 5.366 & $5.639 \pm 0.302$ \\
n-hexane fraction & 7.606 & 7.318 & 6.678 & $7.201 \pm 0.475$ \\
Ethyl acetate fraction & 5.497 & 5.438 & 5.369 & $5.435 \pm 0.064$ \\
Water fraction & 8.839 & 9.142 & 9.421 & $9.134 \pm 0.2911$ \\
Vitamin C & 4.304 & 4.275 & 4.245 & $4.275 \pm 0.029$ \\
\hline
\end{tabular}

Values are expressed as mean $\pm \mathrm{SD}$.

Table 4. Total phenolic content of extract and fraction of jackfruit seed

\begin{tabular}{lcccc}
\hline \multirow{2}{*}{ Sample } & \multicolumn{2}{c}{$\begin{array}{c}\text { Total phenolic content } \\
\text { (g GAE/100 g sample) }\end{array}$} & $\begin{array}{c}\text { Average } \\
\text { (g GAE/100 g } \\
\text { sample) }\end{array}$ \\
\cline { 2 - 4 } & I & II & III & same \\
\hline Methanol extract & 36.309 & 44.622 & 42.712 & $41.214 \pm 4.354$ \\
n-hexane fraction & 50.113 & 47.459 & 46.274 & $47.949 \pm 1.966$ \\
Ethyl acetate fraction & 51.38 & 49.081 & 48.329 & $49.597 \pm 1.589$ \\
Water fraction & 36.451 & 35.432 & 34.63 & $35.504 \pm 0.913$ \\
\hline
\end{tabular}

Values are expressed as mean \pm SD.

\subsection{Determination of total phenolic and flavonoid contents}

Phenolic compounds and flavonoids are the most abundant compounds in plants and responsible for antioxidant activity. Flavonoid and phenolic compounds will donate hydrogen radical to bind to free radicals so that free radicals that enter the body will be stable (Hamid et al., 2010). The phenolic hydroxyl groups in plant substances are responsible for the scavenging of free radicals. Phenolic contents in plant extracts and fractions were measured using the Folin-Ciocalteu method (Aryal et al., 2019). Based on the data in Table 5 , the ethyl acetate fraction of jackfruit seeds had a higher phenolic content than the n-hexane fraction, ethanol extract, and water fraction with values of $49.597 \pm 1.589, \quad 47.949 \pm 1.966, \quad 41.214 \pm 4.354$ and $35.504 \pm 0.913 \mathrm{~g} \mathrm{GAE} / 100 \mathrm{~g}$ of sample, respectively.

The basic structure of flavonoids is a flavan nucleus, which consists of fifteen carbon atoms arranged in three rings, C6-C3-C6, labelled A, B and C. Several types of flavonoids have different degree of oxidation and 
saturation in ring C. Meanwhile, several flavonoids in the same class have different substitution patterns in rings $\mathrm{A}$ and $\mathrm{B}$. The differences in structure and substitution patterns affect the antioxidant properties of flavonoids (Wojdyło et al., 2007).

Table 5. Total flavonoids content of extract and fraction of jackfruit seed

\begin{tabular}{|c|c|c|c|c|}
\hline \multirow{2}{*}{ Sample } & \multicolumn{3}{|c|}{$\begin{array}{l}\text { Total flavonoids content } \\
\text { (g QE/100 g sample) }\end{array}$} & \multirow{2}{*}{$\begin{array}{c}\text { Average } \\
\text { (g QE/100 g } \\
\text { sample) }\end{array}$} \\
\hline & I & II & III & \\
\hline Methanol extract & 59.474 & 59.509 & 60.737 & $59.907 \pm 0.719$ \\
\hline n-hexane fraction & 65.263 & 65.825 & 64.596 & $65.228 \pm 0.615$ \\
\hline Ethyl acetate fraction & 70.351 & 70.561 & 69.684 & $70.199 \pm 0.458$ \\
\hline Water fraction & 54.211 & 54.596 & 53.895 & $54.234 \pm 0.351$ \\
\hline
\end{tabular}

Values are expressed as mean \pm SD.

The total flavonoid content was determined using the aluminium chloride colorimetric method. In principle, aluminium chloride will form stable complexes with a C4 keto group and either the C-3 or C-5 hydroxyl groups of flavonols and flavones. In addition, it can also form unstable complexes with hydroxyl groups in the ortho position in the B-ring of flavonoids (Chang et al., 2002; Al-matani et al., 2016; Sembiring et al., 2018). Flavonoid is needed by the human body to maintain good health (Shi et al., 2019).

Based on the data presented in Table 5, the ethyl acetate fraction of jackfruit seeds had a higher content of flavonoids than the n-hexane fraction, methanol extract, and water fraction, with values of $70.199 \pm 0.458$, $65.228 \pm 0.615,59.907 \pm 0.719$, and $54.234 \pm 0.351 \mathrm{~g}$ of quercetin equivalent/100 $\mathrm{g}$ of sample, respectively.

In relation to the data on antiradical activity $\left(\mathrm{IC}_{50}\right)$ in Table 3, data on phenolic and flavonoid contents presented in Table 4 and Table 5 indicated that there was a correlation between phenolic and flavonoid contents and antiradical power in the ethyl acetate fraction. However, the opposite happened to methanol extract and $\mathrm{n}$-hexane fraction. This was due to the complexity of the compounds in the extract. Thus, the possibility was that the antioxidant power was not solely influenced by phenolic compounds and flavonoids, but was also by other compounds, such as ascorbic acid, tocopherols, pigments, and others. Another possibility was that the phenolic and flavonoid structures in the sample also affected the antiradical power of the material (Kaur and Mondal, 2014).

The correlation of phenolic and flavonoid content with the anti-radical activity of the substance can be determined based on the $\mathrm{R}^{2}$ value of the regression equation between flavonoid or phenolic levels on the $x$ axis and antiradical power on the $y$-axis (Arnous et al., 2001). Figure 2 and Figure 3 presents the $R^{2}$ value of phenolic, which was 0.4582 , illustrating that $45.82 \%$ of the anti-radical power of jackfruit seed extract and fraction was influenced by the phenolic compound. The $\mathrm{R}^{2}$ value of flavonoids was 0.5281 , indicating that the effect of the flavonoid in the extract and fraction of jackfruit seeds was $52.81 \%$.

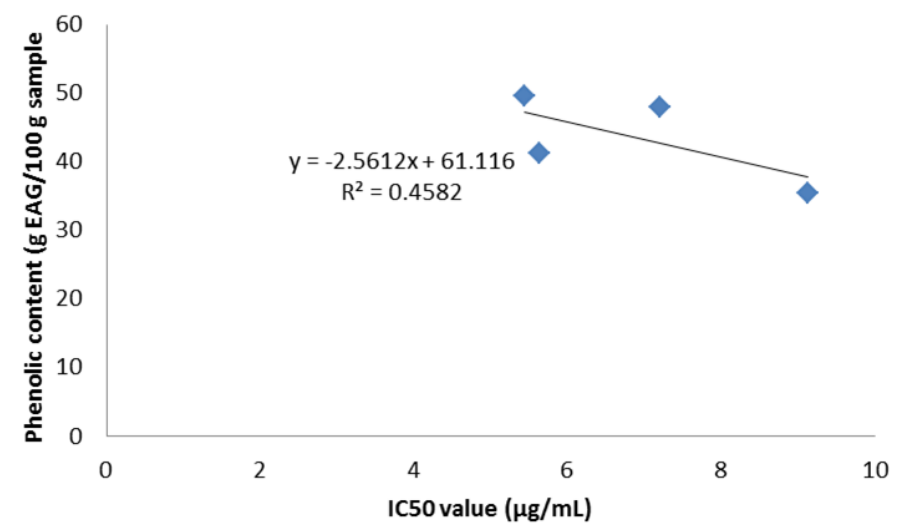

Figure 2. Correlation of phenolic content with IC50 value of jackfruit seeds

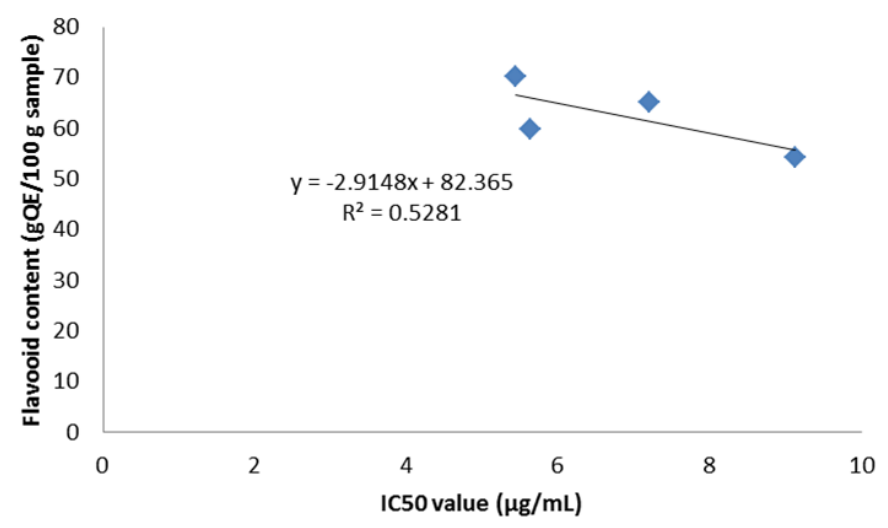

Figure 3. Correlation of flavonoids content with IC50 value of jackfruit seeds

\section{Conclusion}

Methanol extract and fractions of jackfruit seeds were tested for their anti-radical activity using DPPH and they displayed strong anti-radical activity. Ethyl acetate fraction displayed the strongest antiradical activity with an $\mathrm{IC}_{50}$ value of $5.435 \pm 0.064 \mu \mathrm{g} / \mathrm{mL}$. The ethyl acetate fraction had a phenolic content of $49.597 \pm 1.589 \mathrm{~g}$ GAE/100 g of sample and flavonoid content of $70.199 \pm 0.458 \mathrm{~g} / 100 \mathrm{~g}$ of quercetin equivalent $/ 100 \mathrm{~g}$ of sample. The correlation value of $\mathrm{R}^{2}$ of phenolic was 0.4582 , while the correlation value of $\mathrm{R}^{2}$ of flavonoid was 0.5281 . Thus, the ethyl acetate fraction can be further developed as natural antioxidant and as a functional food.

\section{Conflict of interest}

The authors declare no conflict of interest. 


\section{Acknowledgments}

We would like to thank the president of Halu Oleo University that provided a research grant via the Institute for Research and Community Service of Halu Oleo University.

\section{References}

Al-matani, S.K., Al-wahaibi, R.N.S. and Hossain, M.A. (2016). In vitro evaluation of the total phenolic and flavonoid contents and the antimicrobial and cytotoxicity activities of crude fruit extracts with different polarities from Ficus sycomorus. Pacific Science Review A: Natural Science and Engineering, 17(3), 103-108. https://doi.org/10.1016/ j.psra.2016.02.002

Amaro, H.M., Andrade, P.B., Malcata, F.X., Guedes, A.C., Jorge, R.D., Ferreira, V., Frias, R., Process, E.and Frias, R. (2015). Effect of Solvent System on Extractability of Lipidic Components of Scenedesmus obliquus (M2-1) and Gloeothece sp. on Antioxidant Scavenging Capacity Thereof. Marine Drugs, 13(10), 6453-6471. https://doi.org/10.3390/ md13106453

Antasionasti, I., Riyanto, S. and Rohman, A. (2017). Antioxidant Activities and Phenolics Contents of Avocado (Persea americana Mill.) Peel in vitro. Research Journal of Medicinal Plants, 11(2), 56-61. https://doi.org/10.3923/rjmp.2017.55.61

Arina, N.B. and Rohman, A. (2013). The phenolic contents and antiradical activity of Indonesian. International Food Research Journal, 20(3), 11191124

Arnous, A., Makris, D.P. and Kefalas, P. (2001). Effect of Principal Polyphenolic Components in Relation to Antioxidant Characteristics of Aged Red Wines. Journal of Agricultural and Food Chemistry, 49, 5736-5742. https://doi.org/10.1021/jf010827s

Aryal, S., Baniya, M.K., Danekhu, K., Kunwar, P., Gurung, R. and Koirala, N. (2019). Total Phenolic Content, Flavonoid Content and Antioxidant Potential of Wild Vegetables from Western Nepal. Plants, 8(4), $\quad 96 . \quad$ https://doi.org/10.3390/ plants8040096

Azlim Almey, A.A., Ahmed Jalal Khan, C., Syed Zahir, I., Mustapha, Suleiman, K., Aisyah, M.R. and Kamarul Rahim, K. (2010). Total phenolic content and primary antioxidant activity of methanolic and ethanolic extracts of aromatic plants' leaves 1 . International Food Research Journal, 17, 10771083.

Brighente, I.M.C., Dias, M., Verdi, L.G., Pizzolatti, M.G., Dias, M., Verdi, L.G., Antioxidant, M.G.P.,
Brighente, I.M.C., Dias, M., Verdi, L.G. and Pizzolatti, M.G. (2008). Antioxidant Activity and Total Phenolic Content of Some Brazilian Species Antioxidant Activity and Total Phenolic Content of Some Brazilian Species. Pharmaceutical Biology, 45 (2), 156-161. https:// doi.org/10.1080/13880200601113131

Burci, L.M., Bezerra, C., Oliveira, M.De, Dalarmi, L., Zanin, M.W., Miguel, O.G., Fátima, J.D. and Dias, G. (2015). Determination of antioxidant, radical scavenging activity and total phenolic compounds of Artocarpus heterophyllus (Jackfuit) seeds extracts. Journal of Medicinal Plants Research, 9(40), 10131020. https://doi.org/10.5897/JMPR2015.5926

Chang, C., Yang, M., Wen, H. and Chern, J. (2002). Estimation of Total Flavonoid Content in Propolis by Two Complementary Colorimetric Methods. Journal of Food and Drug Analysis, 10(3), 178-182. https:// doi.org/10.38212/2224-6614.2748

Fitriana, W.D., Ersam, T., Shimizu, K. and Fatmawati, S. (2016). Antioxidant Activity of Moringa oleifera Extracts. Indonesian Journal of Chemistry, 16(3), 297-301. https://doi.org/10.22146/ijc.21145

Garcia, E.J., Alencar, S.M.D., Reis, A., Loguercio, A.D., Helena, R. and Grande, M. (2012). Antioxidant Activity by DPPH Assay of Potential Solutions to be Applied on Bleached Teeth. Brazilian Dental Journal, 23(1), 22-27. https://doi.org/10.1590/S0103 $-64402012000100004$

Gupta, D., Mann, S., Sood, A. and Gupta, R.K. (2011). Phytochemical, nutritional and antioxidant activity evaluation of seeds of jackfruit (Artocarpous heterolphyllus Lam.). International Journal of Pharma and Bio Sciences, 2(4), 336-345.

Hamid, A.A., Aiyelaagbe, O., Usman, L.A. and Ameen, M.O. (2010). Antioxidants: Its medicinal and pharmacological applications. African Journal of Pure and Applied Chemistry, 4(8), 142-151.

Ilmi, H.M., Elya, B. and Handayani, R. (2020). Association between total phenol and flavonoid contents in Artocarpus heterophyllus (jackfruit) bark and leaf extracts and lipoxygenase inhibition. International Journal of Applied Pharmaceutics, 12 (Special Issue 1), 252-256. https://doi.org/10.22159/ ijap.2020.v12s1.FF055

Jamuna, S., Paulsamy, S. and Karthika, K. (2012). Screening of in vitro antioxidant activity of methanolic leaf and root extracts of Hypochaeris radicata L. (Asteraceae). Journal of Applied Pharmaceutical Science, 2(7), 149-154. https:// doi.org/10.7324/JAPS.2012.2722

John, B., Sulaiman, C.T., George, S. and Reddy, V.R.K. 
(2014). Total phenolics and flavonoids in selected medicinal plants from kerala. International Journal of Pharmacy and Pharmaceutical Sciences, 6(1), 0 2.

Kaur, S. and Mondal, P. (2014). Study of total phenolic and flavonoid content, antioxidant activity and antimicrobial properties of medicinal plants. Journal of Microbiology and Experimentation, 1(1), 23-28. https://doi.org/10.15406/jmen.2014.01.00005

Matthaus, B. (2002). Antioxidant Activity of Extracts Obtained from Residues of Different Oilseeds. Journal of Agricultural and Food Chemistry, 50, 3444-3452. https://doi.org/10.1021/jf011440s

Mishra, K., Ojha, H. and Chaudhury, N.K. (2012). Estimation of antiradical properties of antioxidants using DPPH assay: Critical review and results. Food Chemistry, 130(4), 1036-1043. https:// doi.org/10.1016/j.foodchem.2011.07.127

Mistriyani, Riyanto, S. and Rohman, A. (2018). Antioxidant activities of Rambutan (Nephelium lappaceum L) peel in vitro. Food Research, 2(1), 119-123. https://doi.org/10.26656/fr.2017.2(1).150

Moke, L.E., Ngbolua, K., Bongo, G.N., Messi, L.M., Noté, O.P., Mbing, J.N. and Mpiana, P.T. (2017). Artocarpus heterophyllus Lam. (Moraceae): Phytochemistry, Pharmacology and Future Directions, a mini-review. Journal of Advanced Botany and Zoology, 5(3), 1-8.

Ningsih, I.Y., Zulaikhah, S., Hidayat, M.A. and Kuswandi, B. (2016). Antioxidant Activity of Various Kenitu (Chrysophyllum cainito L.) Leaves Extracts from Jember, Indonesia. Agriculture and Agricultural Science Procedia, 9, 378-385. https:// doi.org/10.1016/j.aaspro.2016.02.153

Rizkayanti, Diah, A.W.M. and Jura, M.R. (2017). Uji aktivitas antioksidan ekstrak air dan ekstrak etanol daun kelor (Moringa Oleifera Lam.) Antioxidant Activity Tests of Water and Ethanol Extracts of Moringa (Moringa oleifera Lam.) Leaves. Jurnal Akademika Kimia, 6, 125-131. https:// doi.org/10.22487/j24775185.2017.v6.i2.9244

Rohman, A., Riyanto, S., Yuniarti, N., Saputra, W.R., Utami, R. and Mulatsih, W. (2010). Antioxidant activity, total phenolic, and total flavaonoid of extracts and fractions of red fruit (Pandanus conoideus Lam). International Food Research Journal, 17(1), 97-106.

Rohman, Abdul, Riyanto, S., Mistriyani, Shuhaira and Nugroho, A.E. (2017). Antiradical Activities of Rambutan Peel: Study from Two Cultivars. Research Journal of Phytochemistry, 11(1), 42-47. https:// doi.org/10.3923/rjphyto.2017.42.47
Sannigrahi, S., Mazuder, U.K., Pal, D.K., Parida, S. and Jain, S. (2010). Antioxidant Potential of Crude Extract and Different Fractions of Enhydra fluctuans Lour. Iranian Journal of Pharmaceutical Research, 9(1), 75-82.

Sembiring, E.N., Elya, B., Sauriasari, R., Sembiring, E.N., Elya, B. and Sauriasari, R. (2018). Phytochemical Screening, Total Flavonoid and Total Phenolic Content and Antioxidant Activity of Different Parts of Caesalpinia bonduc (L.) Roxb. Pharmacognosy Journal, 10(1), 123-127.

Sharma, O.P. and Bhat, T.K. (2009). DPPH antioxidant assay revisited. Food Chemistry, 113(4), 1202-1205. https://doi.org/10.1016/j.foodchem.2008.08.008

Shekhar, T.C. and Anju, G. (2014). Antioxidant Activity by DPPH Radical Scavenging Method of Ageratum conyzoides. American Journal of Ethnomedicine, 1 (4), 244-249.

Shi, P., Du, W., Wang, Y., Teng, X., Chen, X. and Ye, L. (2019). Total phenolic, flavonoid content, and antioxidant activity of bulbs, leaves, and flowers made from Eleutherine bulbosa (Mill.) Urb. Food Science and Nutrition, 7(1), 148-154. https:// doi.org/10.1002/fsn3.834

Sulastri, E., Zubair, M.S., Anas, N.I., Abidin, S., Hardani, R., Yulianti, R. and Aliyah. (2018). Total phenolic, total flavonoid, quercetin content and antioxidant activity of standardized extract of moringa oleifera leaf from regions with different elevation. Pharmacognosy Journal, 10(6), S104S108. https://doi.org/10.5530/pj.2018.6s.20

Trang, D.H.T., Son, L.H. and Trung, P.V. (2014). Investigation on the in vitro antioxidant capacity of methanol extract, fractions and flavones from Oroxylum indicum Linn bark. Brazilian Journal of Pharmaceutical Sciences, 54, e17178. https:// doi.org/10.1590/s2175-9790201800011717

Vyas, S., Kachhwaha, S. and Kothari, S.L. (2015). Comparative analysis of phenolic contents and total antioxidant capacity of Moringa oleifera Lam. Pharmacognosy Journal, 7(1). https:// doi.org/10.5530/pj.2015.7.5

Widodo, H., Sismindari, Asmara, W. and Rohman, A. (2020). Antioxidant activities of methanolic extract and its fractions of Baccaurea racemosa and Macaranga subpeltata leaves. Food Research, 4(1), 127-134. https://doi.org/10.26656/fr.2017.4(1).144

Wojdyło, A., Oszmiański, J. and Czemerys, R. (2007). Antioxidant activity and phenolic compounds in 32 selected herbs. Food Chemistry, 105(3), 940-949. https://doi.org/10.1016/j.foodchem.2007.04.038

Yamin, Ruslin, Sartinah, A., Ihsan, S., Kasmawati, H., 
Suryani, Andriyani, R., Asma, Adjeng, A.N.T. and Arba, M. (2020). Radical scavenging assay and determination Flavonoid and Phenolic total of extract and Fractions of Raghu bark (Dracontomelon dao (Blanco) Merr). Research Journal of Pharmacy and Technology, 13(5), 2335-2339. https:// doi.org/10.5958/0974-360X.2020.00420.5

Yamin, Wahyono and Susidarti, R.A. (2010). Isolasi dan Indentifikasi Senyawa Antibakteri dari Daun Jakang (Muenhelebeckia platyclada MEISSN). Indonesia: Universitas Gadjah Mada, Thesis. [In Bahasa Indonesia]. 